\title{
Effect of Pruning and Plant Growth Regulator on Plant Growth and Fruit Yield of Sapota (Manilkara zapota L.) cv. Cricket Ball
}

\author{
C.K. Sahu, M.K. Patel* and C.M. Panda
}

Department of Fruit Science and Horticulture Technology, College of Agriculture, Orissa University of Agriculture and Technology, Bhubaneswar-751001, Odisha, India

*Corresponding author

\begin{tabular}{|l|}
\hline Ke y w o r d s \\
$\begin{array}{l}\text { Pruning, Plant growth } \\
\text { regulator, Chlorophyll, } \\
\text { Canopy spread, Leaf } \\
\text { area, Yield }\end{array}$ \\
\hline Article Info \\
\hline $\begin{array}{l}\text { Accepted: } \\
\text { 10 August } 2018 \\
\text { Available Online: } \\
\text { 10 September } 2018\end{array}$ \\
\hline
\end{tabular}

A B S T R A C T

An experiment was carried out during 2017-18inHorticulture Research Station, Bhubaneswar under Department of Fruit Science \& Horticulture Technology, College of Agriculture, Orissa University of Agriculture \& Technology to find out the effect of pruning and plant growth regulator like $\mathrm{GA}_{3}$, IAA, NAA, 2,4-D on plant growth and fruit yield rejuvenated sapota plant. Variation due to divergence in genotypes was found significant so far as the morphometric is concerned highest leaf chlorophyll content (27.85SPAD), canopy spread (11.988m in E-W and $10.51 \mathrm{~m}$ in N-S directions), number of flowers per shoot $(9.61)$, fruit drop $(60.406 \%)$ were observed in unpruned tree. Whereas maximum leaf area $\left(47.616 \mathrm{~cm}^{2}\right)$, fruit set $(13.498 \%)$ were observed in primary branch pruned trees. Among the growth regulators and NAA@50ppm produced highest leaf area $\left(45.974 \mathrm{~cm}^{2}\right)$, no. of flowers per shoot $(8.886)$, fruit set $(15.032 \%)$, no. of fruits per plant (119.4), yield (14.906kg/tree) Whereas GA $@ 20 \mathrm{ppm}$ produced highest chlorophyll content (25.46SPAD), canopy spread $(9.814 \mathrm{~m}$ in E-W \& 8.808m in N-S), fruit weight (134.494g). Hence it is concluded that growth regulator NAA@50ppm influences the yield attributes like fruit set and fruit retention. The treatment combination tip clipping of terminal shoots followed by spraying of NAA @ 50ppm produced highest fruit yield (19.48kg/tree) and was the best among all other treatment.

\section{Introduction}

Sapota produces a large number of flowers throughout the year in different flushes. The fruit quality of October-November flowering (Hasth bahar), which matures during AugustSeptember is somewhat poor as against JulyAugust (Mrig bahar) flowering.

The crop of July-August flowering matures in April-May, when the price is comparatively lucrative. The major problem confronting sapota crop is heavy flower and fruit drop (Patil and Narwadkar, 1974; Farooqui and Rao, 1976). Thus the regulation of flowering is one of the most important practical aspect of sapota cultivation.

India is considered to be the largest producer of sapota in the world. In India at present the total area and production under sapota is estimated as 107,000 hectares and 1294,000 metric tonnes with a productivity of 12.1 mt/ha (National Horticulture Board 2015-16). 
The productivity is very high in Karnataka and Gujurat. It has become most popular fruit crop in Gujurat, Maharastra, Karnataka, Tamil Nadu, Andhra Pradesh and Kerala.

Standardization of canopy management by way of training or pruning to maintain the tree size and to increase productivity has tremendous scope in high density planting of sapota. In senile plant, the yield is decreasing drastically and alternatively vegetative growth increases exponentially. So in order to balance the vegetative and reproductive growth of sapota plant, pruning of branches is felt necessary although fruiting occurs on newly emerged shoots. So to get fruiting from old, unproductive plants pruning is a very good and successive phenomenon for farmers to get some benefit.

Growth regulating chemicals govern all stages of crop development by using these at particular stage of fruit growth and development to have its maximum effect. Different groups of plant growth regulators like auxins, gibberellins and growth retardants at various concentrations have been reported to influence the flowering, fruit set, fruit retention, ripening advancement characters and quality characters of several fruit crops (Das and Mohapatra, 1976). Induction of flowering through chemical means is one way of tackling the problem of excessive vegetative growth and erratic flowering habit (Khader and Rao, 1983). Among the various causes of fruit drop, the simplest oneis hormonal imbalance i.e. decline in the level of endogenous auxins (Addicot and Lynch, 1995).

Among the synthetic auxins tested in this regards, the NAA has been found to be the most effective in chickoo. Keeping this in view, an experiment on "Effect of pruning and plant growth regulator on plant growth and fruit yield of sapota (Manilkara zapota L.) $c v$.
Cricket Ball" was designed with the following cutting edge objectives

To study the effect of pruning and plant growth regulator like $\mathrm{GA}_{3}$, IAA, NAA, 2, 4-D on plant growth and fruit yield rejuvenated sapota plant.

\section{Materials and Methods}

Horticulture Research Station, Bhubaneswar under Department of Fruit Science and Horticulture Technology, College of Agriculture, Orissa University of Agriculture and Technology during the year 2017-18. The experiment was laid out in a split plot design with twenty five treatments replicated twice. In the main plot five levels of pruning and sub plot five levels of growth regulators were studied for their sole and interaction effect. However the $1^{\text {st }}$ pruning was done in 55 years old sapota plant in the year 2013 but subsequently in the present year only 4 healthy shoots with good crotch angle were selected to maintain the primary branch of the pruned tree.

Remaining shoots were thinned out periodically to develop a sturdy framework with open centre system. In secondary and tertiary branch pruned trees, thinning was done. Five levels of pruning were $\left(\mathrm{P}_{1}\right)$ control, $\left(\mathrm{P}_{2}\right)$ tip clipping of terminal shoots, $\left(\mathrm{P}_{3}\right)$ pruning of tertiary branches, $\left(\mathrm{P}_{4}\right)$ pruning of secondary branches, $\left(\mathrm{P}_{5}\right)$ pruning of primary branches and five levels of growth regulators were $\left(\mathrm{G}_{1}\right)$ control, $\left(\mathrm{G}_{2}\right) 20$ ppm $\mathrm{GA}_{3},\left(\mathrm{G}_{3}\right) 50$ ppm NAA, $\left(\mathrm{G}_{4}\right) 100$ ppm IAA, $\left(\mathrm{G}_{5}\right) 20$ ppm 2,4-D as foliar spraying. Observation were taken Leaf area $\left(\mathrm{cm}^{2}\right)$, Chlorophyll content (SPAD), Canopy spread (E-W and N-S), as Growth observations and Yield and yield contributing characters are Number of flowers per shoot, Fruit set percentage (\%), Fruit drop percentage (\%), Number of fruits per plant, Fruit yield (kg/plant), and analysis and 
interpretation of data were done by using the method given by Gomez and Gomez (1984) in split plot design.

\section{Results and Discussion}

Maximum leaf area $(47.616 \mathrm{~cm} 2)$ was observed in P5 followed by P4 $(46.436 \mathrm{~cm} 2)$ and minimum leaf area $(39.994 \mathrm{~cm} 2)$ found in P1 $(39.994 \mathrm{~cm} 2)$. Similarly maximum leaf area $(45.974 \mathrm{~cm} 2)$ was found in $\mathrm{G} 3$ and minimum leaf area $(42.766 \mathrm{~cm} 2)$ found in $\mathrm{G} 1$. This is due to the removal of apical dominance of the woody stems triggering a numerous no. of new shoots to sprang up. Similar findings were reported by Adhikari et al., (2015) in guava and Sahoo et al., (2017) in sapota. Maximum chlorophyll content (27.85 SPAD) was found in P1 and minimum chlorophyll content (22.416 SPAD) found in P5.Similarly maximum chlorophyll content (25.46 SPAD) was found in $\mathrm{G} 2$ followed by G3 (25.008SPAD) and minimum (23.886 SPAD) found in $\mathrm{G} 1$.

The reason being the younger leaves contain the pigment in lesser density than the older leaves. The unpruned trees bear dark green foliage whereas the pruned ones bear light green foliage. Pruning directly stimulates the formation of enlarged leaves, mesophyll size and moisture content as well as lengthen the period of stomata opening. This results a lower chlorophyll content in leaves of pruned trees. These corroborates with the findings of Sharma et al., (2006) in mango and Sahoo et al., (2017) in sapota.

Maximum canopy area in E-W direction (11.988m) was observed in P1 and minimum canopy area $(4.848 \mathrm{~m})$ found in P5. In N-S direction $(10.51 \mathrm{~m})$ was observed in $\mathrm{P} 1$ $(10.466 \mathrm{~m})$ and minimum canopy area (4.614m) found in P5.Maximum canopy area $(9.814 \mathrm{~m})$ in $\mathrm{E}-\mathrm{W}$ direction was found in $\mathrm{G} 2$ and minimum canopy area $(7.448 \mathrm{~m})$ found in
G1. In $\mathrm{N}-\mathrm{S}$ direction maximum canopy area $(8.808 \mathrm{~m})$ found in $\mathrm{G} 2$ and minimum canopy area $(6.852 \mathrm{~m})$ found in G1. This may be due to the conspicuous effect of the growth regulator in elongation of the internode by stimulating the cell division and cell elongation in the meristematic region. These findings agree with that of Brar (2010) and Garhwal et al., (2015).

Average maximum no. of flowers per shoot (9.61) found in $\mathrm{P} 1$ and minimum no. of flowers per shoot (4.24) found in P5. Maximum no. of flowers per shoot (8.886) was found in and minimum no. of flowers per shoot 6.478 found in G1. It seems to have helped to increase the fruit set either by improving pollen germination or by helping the growth of pollen tubes and thus facilitate in timely fertilization before the stigma loses its receptivity or the style becomes nonfunctional. Chavan et al., (2009) worked found NAA $150 \mathrm{ppm}$ produced more number of flowers (54.0) per shoot in sapota.

Maximum fruit set (13.498\%) was found in P5 and minimum percent $(9.958 \%)$ found in $\mathrm{P} 1$. Similarly G3 recorded maximum fruit set $(15.032 \%)$ and minimum $(9.652 \%)$ found in G1.Minimum fruit drop $(51.98 \%)$ recorded in P5 and maximum $(60.406 \%)$ found in P1.Similarly minimum fruit drop (50.564\%) was found in G3 and maximum (60.752\%) in G1). It is found from the result that both auxin and GA enhanced the flower and fruit retention percent but auxin group (NAA and 2, 4-D) are more efficient than gibberellin.

This might be due to anti-abscission property of auxin. Abscisic acid causes dissolution of middle lamella and primary walls of the cell at the base of pedicel and peduncle which leads to detachment of plant organ. However auxin counter acts with the ABA and ethylene and enhanced the Auxin: ABA ratio that ultimately prevents fruit drop (Table 1 and 2). 
Table.1 Effect of pruning on plant growth and fruit yield of sapota (Manilkara zapota L.) $c v$. cricket ball

\begin{tabular}{|c|c|c|c|c|c|c|c|c|c|}
\hline S.I No & $\begin{array}{l}\text { Leaf area } \\
\quad\left(\mathrm{cm}^{2}\right)\end{array}$ & $\begin{array}{l}\text { Chlorophyll } \\
\text { content } \\
\text { (SPAD) }\end{array}$ & $\begin{array}{c}\text { Canopy } \\
\text { spread) (E- } \\
\text { W) }\end{array}$ & $\begin{array}{c}\text { Canopy } \\
\text { spread } \\
(\mathbf{N}-\mathbf{S})\end{array}$ & $\begin{array}{c}\text { Number of } \\
\text { flowers per } \\
\text { shoot }\end{array}$ & $\begin{array}{c}\text { Fruit set } \\
\text { percentage } \\
(\%)\end{array}$ & $\begin{array}{c}\text { Fruit drop } \\
\text { percentage } \\
(\%)\end{array}$ & $\begin{array}{c}\text { Number o } \\
\text { fruits per } \\
\text { plant }\end{array}$ & $\begin{array}{l}\text { Fruit yield } \\
\text { (kg/plant) }\end{array}$ \\
\hline P1 & 46.25 & 26.75 & 10.91 & 9.48 & 8.3 & 11.28 & 61.1 & 132.5 & 13.69 \\
\hline $\mathbf{P 2}$ & 47.51 & 27.85 & 13.4 & 11.36 & 9.27 & 12.43 & 51.69 & 152.5 & 19.05 \\
\hline P3 & 49.35 & 26.74 & 12.57 & 11.29 & 11.37 & 17.49 & 45.1 & 163.5 & 19.48 \\
\hline P4 & 46.65 & 25.75 & 11.38 & 10.02 & 8.46 & 11.91 & 53.47 & 136.5 & 15.68 \\
\hline P5 & 48.32 & 26.42 & 11.68 & 10.41 & 10.65 & 14.38 & 48.54 & 142 & 16.25 \\
\hline Mean & 47.616 & 26.702 & 11.988 & 10.51 & 9.61 & 13.498 & 51.98 & 154.4 & 16.83 \\
\hline $\operatorname{SEm}( \pm)$ & 0.072 & 0.089 & 0.023 & 0.09 & 0.251 & 0.081 & 0.069 & 4.874 & 0.652 \\
\hline CD (5\%) & 0.284 & 0.349 & 0.089 & 0.353 & 0.986 & 0.318 & 0.272 & 19.137 & 2.56 \\
\hline
\end{tabular}

Table.2 Effect of plant growth regulator on plant growth and fruit yield of sapota (Manilkara zapota L.) $c v$. cricket ball

\begin{tabular}{|c|c|c|c|c|c|c|c|c|c|}
\hline S.I No & $\begin{array}{l}\text { Leaf } \\
\text { area } \\
\left(\mathrm{cm}^{2}\right)\end{array}$ & $\begin{array}{l}\text { Chlorophyll } \\
\text { content } \\
\text { (SPAD) }\end{array}$ & $\begin{array}{l}\text { Canopy } \\
\text { spread } \\
(\mathrm{E}-\mathrm{W})\end{array}$ & $\begin{array}{c}\text { Canopy } \\
\text { spread } \\
(\mathrm{N}-\mathrm{S})\end{array}$ & $\begin{array}{l}\text { Number of } \\
\text { flowers per } \\
\text { shoot }\end{array}$ & $\begin{array}{c}\text { Fruit set } \\
\text { percentage } \\
(\%)\end{array}$ & $\begin{array}{c}\text { Fruit drop } \\
\text { percentage } \\
\qquad \%)\end{array}$ & $\begin{array}{c}\text { Number } \\
\text { of fruits } \\
\text { per } \\
\text { plant }\end{array}$ & $\begin{array}{c}\text { Fruit } \\
\text { yield } \\
\text { (kg/plant) }\end{array}$ \\
\hline G1 & 41.32 & 27.85 & 13.4 & 11.36 & 11.37 & 12.16 & 56.27 & 152 & 16.01 \\
\hline G2 & 44.8 & 26.7 & 13.42 & 12.32 & 10.35 & 13.33 & 55.36 & 163.5 & 19.48 \\
\hline G3 & 46.59 & 25.2 & 10.16 & 9.65 & 9.98 & 15.72 & 49.26 & 143 & 19.35 \\
\hline G4 & 47.81 & 24.09 & 6.54 & 5.73 & 7.28 & 16.46 & 47.64 & 112 & 15.82 \\
\hline G5 & 49.35 & 23.46 & 5.55 & 47.98 & 5.54 & 17.49 & 45.1 & 26.5 & 3.87 \\
\hline Mean & 45.974 & 25.46 & 9.814 & 8.808 & 8.904 & 15.032 & 50.726 & 119.4 & 14.906 \\
\hline $\operatorname{SEm}( \pm)$ & 0.097 & 0.145 & 0.03 & 0.079 & 0.134 & 0.075 & 0.065 & 1.448 & 0.183 \\
\hline CD (5\%) & 0.287 & 0.429 & 0.087 & 0.234 & 0.396 & 0.221 & 0.192 & 4.272 & 0.541 \\
\hline
\end{tabular}

Highest no. of fruits (145.4) found in P2 and lowest no. of fruits (19.7) in P5. Similarly G3 recorded the highest no. of fruits (119.4) and lowest no. of fruits were recorded in G1 (88.3). It might be due to GA mediating process for faster translocation and mobilization of stored metabolites or photosynthates from source to sink. It may be due to involvement of auxins in cell division and translocation of food material.

These findings corroborates with Agrawal and Dikshit (2008), Ingale et al., (2008), Chavan et al., (2009), Bhujbal et al., (2013), Garhwal et al., (2015), Joshi et al., (2015) and Sahoo et al., (2017).

Maximum yield (16.83kg/plant) observed in $\mathrm{P} 2$ and minimum yield $(2.606 \mathrm{~kg} / \mathrm{plant})$ found in P5. Similarly highest yield (14.906kg/plant) observed in G3 and lowest yield $(9.574 \mathrm{~kg} / \mathrm{plant})$ in G1. This is because with increased in number of fruits per tree that ultimately increased the yield/tree and yield/ha. Agrawal and Dikshit (2008) reported that the application of NAA considerably increased number of fruits as well as yield than GA. 
Primary pruning of old senile branches resulted a better leaf area than unpruned tree providing more scope for photosynthesis. Furthermore the fruit set and retention percentage remained highest due to enhanced photosynthesis and accumulation of food reserves. Spraying of growth regulators on sapota crop resulted that NAA@50ppm stimulates the leaf area, no. of flowers per shoot, fruit set $\%$, fruit retention $\%$, no. of fruits per plant and yield with minimum fruit drop.

\section{References}

Adhikari S and Kandel TP. 2015. Effect of time and level of pruning on vegetative growth, flowering, yield, and quality of guava, International Journal of Fruit Science, 15 (3): 290-301.

Agrawal S and Dikshit SN. 2008. Studies on the effect of plant growth regulators on growth and yield of sapota (Achras Sapota L.) Cv. Cricket ball, Indian Journalof Agricultural Research, 42 (3): $207-211$.

Ahmad S, Chatha MZA, Aziz NA, Virk NA and Khan AR. 2006. Effect of pruning on the yield and quality of kinnow fruit, Journal of Agriculture and Social sciences. 2 (1):51-53.

Bhujbal DS, Naik DMand Kale SA. 2013. Studies on effect of growth regulators on flowering, fruiting and quality of sapota, International Journal of Agricultural Sciences, 9 (1): 289-292.

Chavan, SR, Patil MB, Phad GN and Suryawanshi AB. 2009. Effect of growth regulators on flowering and yield of sapota [Manilkara achras (Mill.) Forsberg], The Asian Journal of Horticulture, 4 (1): 119-120.

Daberao M D, Joshi PS and Satkar K. 2016. Effect of growth promoting substances on the fruit quality of rejuvenated sapota orchard, Biological sciences, 9 (8): 1542-1546.

Dikshit, SN, Singh PN, Shukla N, Geda AK, Saxena RR and Agrawal S. 2004. Studies on the effect of plant growth regulators on growth, flowering, yield and quality of sapota (Achras sapota L.) cv. Cricket Ball under Chattisgarh plains, Krishikosh, 256:25-29.

Garhwal PC, Ramadevaputra VM. 2015. Effect of $\mathrm{SADH}$, NAA and $\mathrm{GA}_{3}$ on growth, yield and quality of sapota [Manilkara achras (Mill.) Forsberg] CV. Kalipatti, Krishikosh.

Joshi P, Sahoo AK, Daberao MD, Shinde GS. 2016. Effect of different growth promoting substances on rejuvinated sapota plants, Indian Journal Dry land Agriculture Res. and Dev, 31 (1): 63-67.

Kaundal GS, Singh S, Kanwar GS, Chanana YR. 2002. Effect of pruning techniques on growth, production, quality and nutrient status of peach cv. Pratap, Journal of Research PAU, 39 (3):362367.

Kher R, Bhatand S. and Wali VK. 2005. Effect of foliar application of $\mathrm{GA}_{3}$, NAA and CCC on physico-chemical characteristics of guava cv. Sardar, Haryana Journal of Horticultural Sciences, 34 (1/2):31-32.

National Horticulture Board. 2014. Database. Area, production, productivity of major fruit crops in India, www. nhb.gov.in

Patil MB, Munde GR, Nainwad RV and Mane SS. 2011.Studies on effect of plant growth regulator on physical characters of sapota, The Asian Journal of Horticulture, 6(1): 98-100.

Patil MB. 2006. Effect of growth regulators and boron on yield and quality of sapota and boron on yield and quality of sapota [Manilkara achras (Mill.) Forsberg], Journal of Eco-Friendly Agriculture, 1 (2):165-167. 
Samant SP, Polara ND. 2017. Effect of plant growth regulators on flowering, yield and quality of sapota [Manilkara achras (Mill.) Forsberg] cv. Kalipapatti, 2442.

Shrivastava DK and Jain DK. 2006. Effect of urea and $\mathrm{GA}_{3}$ on physiochemical properties of mango cv. langra during on year, Karnataka Journal of Agriculture Science, 19 (3): 754-756.

Singh P, Panigrahi HK. 2009. Studies on the effect of plant growth regulators on fruit retention, fruit drop, yield, ripening and physico-chemical composition of sapota (Manilkara achras Mill.) cv. Cricket Ball under agro climatic condition of Chhattishgarh plains, Krishikosh.

Yadav PK, Yadav AL and Goley G. 2016. Effect of pruning intensity and different levels of potassium chloride on physicochemical attributes of phalsa fruits (Grewia subinaequalis D.C.), Research in Environment and Life Sciences, 9 (5): 606-608.

\section{How to cite this article:}

Sahu, C.K., M.K. Patel and Panda, C.M. 2018. Effect of Pruning and Plant Growth Regulator on Plant Growth and Fruit Yield of Sapota (Manilkara zapota L.) cv. Cricket Ball. Int.J.Curr.Microbiol.App.Sci. 7(09): 1352-1357. doi: https://doi.org/10.20546/ijcmas.2018.709.161 